\title{
Radical masculinity: morality, sociality and relationships through recollections of Naxalite activists
}

\author{
Henrike Donner
}

Published online: 5 November 2009

(C) Springer Science+Business Media B.V. 2009

\begin{abstract}
In this article I argue that the concern with gender relations and the challenges female activists were facing foreclosed any discussion of the transformation activism signalled for male comrades, and thus for wider society. I am particularly interested in men's own views of their social roles and personal predicaments as the more subtle processes of transformation in the lives of male activists are often overlooked. The article takes a closer look at relationships between men, whether friendships or kin relations, as important roles and everyday practices former activists were/are involved in-during their phase of active participation, but crucially also before they become militants and in the aftermath of their involvement in the movement.
\end{abstract}

Keywords India - Maoists · Activism - Masculinity - Gender · Memory · Life histories · Calcutta $\cdot$ Naxalite $\cdot$ Friendship $\cdot$ Kinship · Morality

\section{Introduction}

This article explores the changing ideals and norms of masculinity among middleclass activists who were involved in the Naxalite movement in urban Bengal during the 1970s. Ideals and norms of femininity and the participation of women in the movement have received considerable attention, partly because the movement promised women agency beyond the narrow limits of family and village (Mitra 2004; Bandyophadyay 2008). Female activists have criticised the gender-blindness of the movement and the sexism of male activists, and scholars taking up a gendersensitive approach focused exclusively on women's agency and have failed to take men's experiences seriously (see for instance Panjabi 1997; Roy 2007; Sinha-Roy

H. Donner ( $\square)$

London School of Economics and Political Science, London, UK

e-mail: f.h.donner@1se.ac.uk 
2007). Implicit is the assumption that men who joined the 1970s Maoist struggle did not question patriarchal practices and gendered stereotypes, failed to construct alternative gender roles for themselves, and remained largely unreconstructed.

My material stems from interviews with former activists who were involved in the movement in the late 1960s and early 1970s. The activists concerned were at the time of the interviews in their late 50s to 80s-and had formed part of the inner circle of the Communist Party of India (Marxist Leninist). They took part in urban campaigns before the movement was forced underground and witnessed a huge number of comrades being either shot or imprisoned.

Chopra et al. (2004) suggest that anthropological approaches to the study of masculinity in South Asia usually reiterate a rigid opposition between the renouncer and the householder. This conceptual division has been particularly powerfully employed in relation to political biographies that emerged from the colonial period onwards. However, as the authors cited show, far from being models for male behaviour, such ideal types are open to interpretation. To make sense of the complex realities of gendered identities, any ideological elements need to be situated in concrete relationships and situations, and while gender relations are crucially important in this endeavour, the roles of masculine persons encompass more than relationships between men and women.

In this article, I focus on identities, which are more often than not excluded from debates about South Asian masculinities, but even more neglected in the writings on the Naxal movement. These identities address relationships beyond marriage, and focus in particularly on the-not necessarily erotic-kin relations and friendships between men. After a brief introduction of the Naxal movement in the 1970s, and a summary of the way it is represented and remembered in vernacular discourses, the article discusses relationships between men and the specificities of the patriarchal environment that produced male activists, shaped their involvement with the movement, and determined the afterlife of these experiences.

\section{The movement}

West Bengal was until recently arguably one of the most stable states in India, so much so that the clashes over land allocations for Special Economic Zones between protesters and police in Singur and Nandigram came as a surprise to many casual observers. ${ }^{1}$ But up until the Left Front government headed by the Communist Party of India (Marxist) (CPI(M)) came to power in 1977, West Bengal had been a hotbed of widespread unrest and campaigns challenging the status quo. These were mainly carried out by the then oppositional Communist Party of India (CPI), which led mass mobilisation drives in the rural areas of Bengal, and destabilised consecutive governments already struggling with the massive influx of refugees in the aftermath of partition.

The developing culture of protest came to a head in the late 1960s when the armed uprising in Naxalbari, a rural site in North Bengal, which was to give Maoism

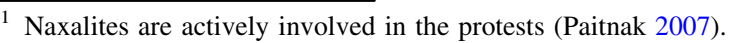


in India its name, fronted by Kanu Sanyal and Charu Majumdar provoked the state government, including its Communist faction, into direct confrontation. By 1967, the Central government imposed special administrative powers, so-called President's Rule, in Bengal for the first time, and did so again after fresh elections in 1969 during which the Communist Party of India (Marxist) had won a large number of seats.

It is important to note that Naxalbari and the rise of the Maoist movement in India did not signify a sudden outburst of peasant resistance, but resulted from extensive Communist agitations, not only in rural Bengal but also in other states where Communists had organised peasants from the 1930s onwards (see Ray 1988; Basu 2000). In Bengal, the movement drew on the experience and personnel of mass struggles like the Tebhaga sharecropper mobilisation. But a further precondition for the rise of the Maoist groups was the history of factionalism within the Communist movement, which first resulted in the split between the all India Communist Party (CPI) and the Communist Party (Marxist) (CPI(M)) and later the breakaway of the Maoist factions, some of which formed the Communist Party (Marxist-Leninist). The latter process gave birth to the wider Naxalite movement, which is seen today as an essential part of this wider post-independence currents of Left wing politics. ${ }^{2}$

Following clashes in the districts, the formation of a Maoist party took shape with seasoned comrades joining the All India Committee of Communist Revolutionaries (AICCR) in 1968, and after the Chinese government had embraced the 'spring thunder of revolution' it saw in the Naxalbari uprising. The Committee transformed itself into the CPI(ML) as more and more organised Communists sided with the rebel faction among the Bengali section, and in the brief period during which the movement was active, students, landless labourers and peasants were recruited. Calcutta became the centre of urban Maoist activities and guerrilla warfare as thousands of predominantly young, educated and mostly male middle-class youths were recruited directly in schools and colleges. In the few years the party was fully operational the city to politicise villagers, but in the view of the party equally important were the campaigns to boycott elections and examinations, and attacks on class enemies, which included urban activities. Street battles with political opponents, further mobilisation in schools and colleges, and study circles in which they read the writings of Mao and Charu Majumdar, convinced students that they followed the example of the Red Guards, though only a minority adopted what became known as the 'annihilation line'. ${ }^{3}$

The movement was brutally oppressed by Central government forces, which were employed to hunt down and often assassinate activists in their thousands. The 'West Bengal (Prevention of Violent Activities) Act' of 1970 and the 'Maintenance of Internal Security Act' of 1971 introduced legislation to legitimise 'antiterrorist' measures, including detention without counsel and the shooting of arrested suspects.

\footnotetext{
${ }^{2}$ For detailed discussions see Franda (1971), Nossiter (1988), and Basu (2000). For accounts of the ideology, structure and repression of the Naxal movement itself see Dasgupta (1974) and Ray (1988). Charu Majumdar's writings on strategy are provided by the Maoist Documentation Project at http://www.maoism.org/misc/india.

3 This refers to the killing of 'class enemies'.
} 
These laws were expanded during the 'Emergency' under Indira Gandhi to surpress any opposition nation-wide.

Most leading Naxalites were arrested by 1971, and after Charu Majumdar's death in custody 1972, the CPI(ML) ceased to exist as a significant political organisation in West Bengal, though many comrades remained active. Calcutta saw the gradual decline of militant politics. However, the 'restoration of law and order' in the aftermath of this period, during which thousands of alleged Naxals had been arrested and killed, took years. Many activists remained imprisoned until a general amnesty was granted when the CPI(M)-led Left Front came to power in 1977. ${ }^{4}$

Over the next 10 years, the CPI(M) established itself as the most powerful political player in West Bengal, and its hegemony has only very recently been seriously challenged. Supported by a strong rural vote bank, thier populist politics have won them every election since, and they have built up a well-functioning party apparatus.

\section{Remembering Naxalbari}

The CPI(M) came to power in 1977 because the electorate demanded a regime change after the preceding period of disruption and political unrest. With the general amnesty, Naxalbari turned into a chiffre for political crisis and chaos as well as regional revolt against the Central government. Pockets of continuous Maoist activity notwithstanding, a revival of the movement seemed unlikely. But while the official appropriation of the revolution by the CPI(M) took off, public silences about the legacy of the Naxalite movement did not make it disappear.

Apart from the obvious interest any sociologist of the current movement would have in this history, the repression of Naxalbari has had a major impact on Calcuttans in general, and the Bengali middle class in particular. The violence unleashed by the movement and the counterinsurgency forces, the number of those killed, imprisoned, and those who vanished or were forced to go underground, prevented these events from sinking into oblivion. But at the same time, as individuals and families started to come to terms with the aftermath, the politics of protest were formalised, and personal as well as collective memories were suppressed and streamlined. The words of a friend spoken in the mid-1980s, 10 years after the amnesty, resonated in many conversations I had much later: 'Every Calcutta middle-class family has lost someone, either a son, a brother, or a cousin'. In the meantime, the movement has been successfully and extensively eulogised as part of vernacular cultural production, which reflects these sentiments and aspirations, but has also canonised it in the form of a separate genre, referred to as 'Naxal literature' (naxal sahitya). A mixture of fiction and 'testimony', these stories, autobiographies and poems present a symbolic reconstruction of this violent past, and provide a fertile ground for coherent, readily available and appealing collective memories of these traumatic social events (Iguarta and Paez 1997). In the

\footnotetext{
4 By 1977 about 18,000 arrests had been made under the 'Maintenance of Internal Security Act' in West Bengal alone (Nossiter 1988:136).
} 
absence of official memorials, books, plays and films form a major source for the reconstruction of 'Naxalbari' in the public sphere (for instance Banerjee 1987; Devi 2001; Mitra 2004). But they also perpetuate various myths, for instance the notion that most students who joined the movement belonged to elite institutions and that the movement wiped out 'the best', whereby the contribution of less privileged students is minimised. This bias towards elite representations also informs scholarly representations, including the accounts of historians and social scientists (see Franda 1971; Dasgupta 1974; Ghosh 1974).

The everyday legacy of the movement, however, can be found elsewhere and is transmitted as part of family histories and recollections of political involvement among ordinary people in various, often surprising forms. In the course of my fieldwork, it became apparent that official and canonised accounts of Naxalbari differ significantly from personal recollections of those, who were actively involved in different capacities, be it as activists, friends, family or opponents of the movement. 5

After a brief sojourn, I therefore focus primarily on interviews with male activists, which took place 30 years after the events they are referring to occurred.

\section{Personal memories}

The CPI(M)'s regard of the Naxalites as dangerous enemies and their engagement in counterinsurgency measures meant that the party had no interest in formally acknowledging the Naxalite presence. So while 1977 brought an amnesty for all political prisoners, Communist rule precluded any attempt to get justice. However, 'Naxalbari' figures as an important part of autobiographical representations in Calcutta. One such instance was my conversation with Shankar Moitra, a middleaged Bengali engineer who had lived in Germany since 1967, but had been born as the eldest of four siblings into a middle-class Calcutta family. Talking about his younger brother, a former Naxal activist, who unlike him had remained in Calcutta when the first signs of trouble at his college became apparent, Shankar revealed that the unrest in educational institutions was one reason why he was sent abroad on a scholarship. While Shankar dutifully completed his engineering degree and got himself a job, his brother moved around the Eastern districts organising peasants.

With his brother being forced underground into many years in hiding, Shankar met him only once, in a safe house. But for his parents and siblings such clandestine meetings, surveillance and harassment by police and the constant worry that he might be arrested marred the memory of these years. Though Shankar's brother was lucky enough and did not fall into the hands of the police, who would have no doubt tortured and possibly shot him, Shankar spoke movingly about the grief his brother's activism caused his parents and siblings. While Shankar regretted not to have been in Calcutta during that important period of politicisation, he was also clearly very angry with his brother, who interrupted his education, disappeared for

\footnotetext{
5 'The Naxalites through the eyes of the Police' edited by A.K. Mukhopadhyay explores the role the police played during this period (Mukhopadhyay 2006).
} 
years, and left his mother heartbroken without a son at home. The harassment his parents endured at the hands of the police and the fact that his brother did not marry and only barely managed to keep the family firm afloat after he returned home in the early 1980s, left the other family members very bitter.

A very different conversation brought up Sharmila's memories, when I talked to her a married mother of two in her forties. We were discussing love marriages while going through some family albums with her daughter when she rather casually pointed out a young man with a long beard wearing a khadi kurta, and explained to her "This is your mama, the one who had become a Naxal and was shot during an encounter with the police." She then turned to me, adding, "If he had not become an activist, things would have been different for me, we were very close and I may not have married [my husband], but since he had been gone things were not the same at home and I just wanted to get out."

For activists, but also for many non-activists, the present is clearly a result of the Naxal period, whether this is a metaphor for law-and-order problems, or a marker of rupture in their personal lives (see Dasgupta 1996; Mitra 1985).

While these examples go to show how the movement comes up in conversations about a range of subjects in the private lives of Calcuttans, the role highlighted in the narratives is that of brothers, or better, absent brothers, who turned into activists and failed to provide support to a sibling and their parents. But the role of siblings, and especially of brothers, is only one in a set of important relationships for South Asian men which contribute to the kind of hegemonic bourgeois masculinity that is socially acceptable and aspired to in urban Bengal.

The vignettes presented above provide a window into popular representations of the Naxal movement, and also open up the discussion of what being an activist meant in the everyday lives of various actors. The following section takes a closer look at how activism emerged from, but simultaneously challenged, expectations and transformed the relationships which constitute middle-class masculinity in urban Bengal.

\section{Relationships between men: families and comrades}

Chopra et al. (2004: $28 \mathrm{pp}$ ) suggest that while in order to analyse masculinities we have to situate them within the wider framework of gender relations, we also need to look at relationships between men. In the Naxal movement, young men formed very strong bonds with comrades their own age, both, male and female, but also with older men. Younger activists were often recruited by a teacher or professor, and they turned their back on their families when they entered into close relationships with these figures of authority. While the 'key paradigm that encodes forms of hierarchy between men' is here, as elsewhere, the father-son relationship (Chopra et al. 2004, p. 31), we need to unpack stereotypical notions of what being an activist entailed in order to see the significance of personal relationships in political activism.

Contrary to the public focus on the very authoritarian character of Maoist organisation, which was no doubt exacerbated by the pressure of counterinsurgency measures, former activists emphasised that the everyday reality of relationships 
within the movement was often significantly different from other spheres of life. Among those I interviewed, a significant number were recruited as cadres straight from school, and it was often these men who were adamant that although a certain respect akin to that for a teacher was paid to leaders, relationships developed over time did not always conform to the ideal of the teacher-pupil model.

\section{Challenging parental authority}

But relationships within the movement were not the only significant relationships activists were eager to talk about. Equally important was their representation of relations with men in their families, especially fathers and older siblings. First, let me introduce the background of these young cadres through the written account of Subroto, who joined in his teens in his own words:

I was born in a middle-class family of Calcutta in 1952. We were not affluent, yet we had a smooth lifestyle. My mother was thoroughly a nationalist and had a genuine love for literature that had influenced us all to come out of the narrow domestic boundary. Even after a day-long hard domestic labour, she used to read some sort of literature. In this connection, I had to go to the local library quite often to bring books for her. And whenever I brought some books of inferior standard she would certainly rebuke me in that context. I can remember, I used to argue with her. And this process had ultimately injected some literary taste in me as well. The life of us-myself, my brothers and sisters - six in all-moved around our mother. My father served in a British firm-he was a meticulous professional, and remained aloof to household affairs. My elder brother is an engineer, he was a brilliant student and was never involved in politics. After graduation he had founded a small scale industry. Hard labour and professional skill brought success to him. The next is a lecturer in philosophy in a Calcutta college, who once was involved in fancy politics, and at present keeps a distance from politics. The third born was deeply involved in Naxalite politics, had great potential and resigned from service for the cause of politics. At present he leads the life of a private tutorand that's all. His, as well as my participation in the Naxalite movement had invited oppression by the administration on our family, which virtually destroyed normal life. And as a consequence, my mother died an immature death of infinite mental stress. From my early boyhood days I was a sort of romantic fellow, who has a mystic world of his own. This compelled me to get thoroughly involved in the political whirl in such a boyhood state. Browsing different leftist journals, I had a hazy idea of socialism. There was the influence of my brothers on me. Above all, the food movement in Bengal and the Leftist movement in support of the heroic struggle of the great Vietnamese people had allured me to join a popular political movement. ${ }^{6}$

Men like Subroto placed themselves very consciously within the social framework of a stratified middle class. This implied that the remote chance to

\footnotetext{
${ }^{6}$ English in the original.
} 
gain a job hinched on his successful completion of higher education. Parents like his, who struggled to provide for relatively large families, gradually began to realise that students involved in the movement were prepared to forego careers for the sake of the revolution. While many of the theoretical ideas, questions of inequality, a critique of existing nationalist history, and aversion to authority formed part and parcel of political identities from the colonial period onwards, children were of course not brought up to join an armed struggle. As the disruption of college life became more severe, better-off families decided to send their sons abroad, while less affluent families like Subroto's tried to muddle through. Most parents realised too late that the institutions were unable to bear the pressure and that the students were in a permanent state of revolt and unrest. This realisation was followed by months of uncertainty, with more and more pupils and students immersing themselves into politics, and many dying at the hand of paramilitary forces.

Not surprisingly the rupture associated with 'Naxalbari' is thus also depicted as a source of conflict within the family. Education was seen as a contractual arrangement which formed part of reciprocal flows between generations (see Lamb 2000). When a son discontinued his education to join the movement he sacrificed not only his own career prospects, but also the possibility of fulfilling filial roles and expectations. This commitment was often described in terms of sacrifice, a concept that was carried over into the movement from nationalist rhetoric (Ray 1988), but gained an even broader currency. Former activists I interviewed employed it as a raison d'etre that linked political and family relationships. While fathers were often depicted as distant, authoritarian figures, mothers were described as 'worrying', 'suffering' and projecting their own vulnerability through a discourse that made their self-sacrificing sons feel very guilty. But students would experience their engagement within the movement as a shift from the guardianship of their parents to the guardianship of leaders. The authority of the leaders seems less to have substituted for parental authority, than supplemented it, and was often initially accepted by parents. In the spirit of shared parenting common in South Asian families, teachers can take on quasi-parental roles and are expected to support a son or daughter later on in life. The emotional involvement in these relationships and the influence of teachers over their charges beyond the school or the campus was therefore not unusual and may have been even encouraged by parents.

The acceptance of his close relationship with his teachers was certainly felt by Suresh, who was recruited into a small group of cadres early on. A gentle and softspoken man in his early 50s when I met him, Suresh was the youngest of three sons and lived with his parents and his brothers in North Calcutta. Like many others, he interpreted the movement and his own involvement almost entirely in terms of personal relationships - the betrayals encountered, the friendships formed, and his marriage to a fellow activist.

His personal narrative began with his father, a brute, who ran his house in an authoritarian manner and was especially abusive towards servants. His 'semifeudal' mindset led to permanent conflicts between father and son, which culminated when Suresh ran away from home. In Suresh's account his father's attitude had a strong impact on his moral development and led him towards joining a group of politicised students. He described the various campaigns, like the 
destruction of a school laboratory and the smashing of statues, he took part in. He also hinted at violent clashes with college staff, and revealed that he was involved in the stabbing of a 'class enemy' in his locality. While he was in the party, Suresh regarded the leaders with great respect, and as suggested earlier, the line between the authority of the family and the authority of the party became blurred. Emulating the Red Guards, Suresh wanted to leave school only months before his final exams. However, although the CPI(ML) promoted the boycott of exams, the local leaders forced Suresh to rethink his decision when they found that his mother had threatened to commit suicide. Suresh's superiors persuaded him to accept that it actually was a sign of strength to fulfill his filial duty. ${ }^{7}$ He later followed his comrades into a more adventurous life and ultimately was imprisoned in 1971.

When he went underground shortly afterwards, Suresh, like many of my informants, was involved in the publication unit of the CPI(ML). Though very much their junior, he felt that the interaction with party leaders, including Charu Majumdar, enhanced his own development as a 'human being' since the unit not only published regular issues of various magazines but also facilitated training for the young men involved.

In 1977, Suresh returned from prison and married a fellow activist, the sister of another local Maoist. The couple moved in with Suresh's family. But apart from problems of adjusting to this domestic life, Suresh found that, without a university degree white-collar employment was difficult to come by. The financial hardship and his dependency on his father drove him to despair, and he decided to return to life as a political activist and joined a newly formed Maoist unit in Madhya Pradesh. There this small group of idealists struggled for two years, but eventually the experiment failed and Suresh returned to his wife, with whom he later had a son.

Suresh's account testifies to the importance of the process through which activists were politicised, which was often triggered by personal experiences and the way the movement allowed them to reinterpret these predicaments. In his case, this included his critique of his father's 'semi-feudal' attitude, but also his submission to the authority of the leading cadres.

However, while family conflicts may have triggered political involvement in his and other cases, life after prison in the 'outside' world made many activists more dependent on their families. Most of the younger activists lacked qualifications, and the vast majority were physically and psychologically scarred. Suresh himself told me 'This was the hardest bit, I had already been back to ask my father for money to support myself, and it was still not enough to survive there, so we had to give up.' He took employment as a clerk but found it hard to adjust to the everyday humiliation of such an inferior position.

But picking himself up, again in a move that he shared with others, he decided to go against the grain and challenge what seemed to him unbearable conditions, partly by renegotiating given roles in his own home:

One day the supervisor said: You are just a clerk, you are not even a graduate (...) that hurt me and I felt that I should do something about it. So I joined

\footnotetext{
7 This and comparable instances demonstrate how the CPI(ML) established a hold over the personal lives of its members.
} 
college and studied English — my wife was supporting us during that time-we managed somehow. After completion of the course I found employment in a research institute and we had a son-since then all these problems are much more easy to bear.

In a very unusual twist, Suresh and his wife agreed that while he was enrolled for a full-time degree (and after they had a son) she would take up employment. This decision was in his view a direct result of his experience and the kind of self he had created as a former Naxalite.

And his was not an exceptional case-Subroto, whose life history is presented above, worked out a comparable arrangement with his wife. When he was released, he was suffering from debilitating depressions. Since he left school as a teen, he could not enrol for a university course and at the time his older brother, with whom he stayed, made an effort to find him a placement in business. But his attempt at self-employment failed miserably. Subroto agreed to marry the niece of a Congress party leader and has since then been in and out of different jobs. Like Suresh, Subroto found it extremely challenging to adjust to formal hierarchical relationships with employers and had to quit various appointments. In the meantime, he and his wife had a son, and with this new commitment she took on a job outside Calcutta, where the family can afford to lead a modest life.

While Subroto finds it much more difficult to accept his own failure to provide for his family, like Suresh he is well aware of the sacrifice his wife and his son are making. These two men had very different marriages, as one chose a comrade, the other agreed to an arranged match. However, both women were forced to take on paid employment outside the home, and both husbands owned up to this extra commitment on their wives' part, which they agreed has also had an influence of how they bring up their respective sons.

Teachers and students

In the accounts of former activists, the history of their own political recruitment is of course not limited to their recounting of family problems and conflicts with parents. At least among the younger generation of Naxalites the figure of the teacher usually played an important role in the way the movement transformed their ideas about what it meant to be a man. All the young cadres were recruited while they were still at school or college, often located in suburban townships. But a number of more prominent institutions, whose students did stand a good chance of acquiring a job, were also hotbeds of Naxal activism. However, in the years preceding the political unrest, most graduates had only minimal chances to find employment, and thus their future looked bleak. In the accounts I have recorded it appears that the way education was imparted differed from school to school and from college to college, but students generally found themselves in an educational landscape dominated by chronically under-funded institutions whose success depended largely on the congeniality of specific heads and teachers. Thus, students who wanted to pass the notoriously unpredictable exams had to foster close personal relationships with 
members of staff, and often it was this 'special' teacher who recruited his charges into the movement.

The example these men set and their pupils' relationships with them, are another route to explore radical masculinities, and the multiple ways in which the experience of the Naxal movement posed a challenge to hegemonic models. During my fieldwork I had intensive conversations with men belonging to both generations of activists, those who joined as young students, and those who were already seasoned cadres and broke away from the existing parties. The latter's political life did obviously differ from that of the younger generation, but old hands often saw it as ideologically and practically productive to work with young cadres. I have outlined these inter-generational differences seen from the perspective of these seasoned cadres elsewhere (Donner 2004a), so I will limit myself here to a general discussion of the relationship between the two groups of men as reflected in the accounts of younger cadres, who joined the movement without any previous experience.

While the interdependence between the older generation and the young students was seen by wider society as comparable to the paradigmatic bond between a father and a son, or a guru and his disciple, everyday life in the movement did change some of the parameters and behaviours expected in such hierarchical relationships. Unlike the Red Guards in China, who routinely questioned the authority of their elders, the Naxalites did not address inter-generational conflicts formally, and the former activists did not suggest that the 'new era' they wanted to establish necessitated a direct attack on their own parents, although the values of bourgeois society were despised. However, the movement did promote challenges to parental authority in terms of recruitment, and through its open acceptance of sexual freedoms, as well as the more subtle egalitarian practices encouraged among male comrades.

In the context of the organisation itself, the overlap of teacher/leader categories allowed the older generation to down-play inter-generational tensions, and especially Charu Majumdar was greatly revered and seen as an inspiring father figure, as a quote from another interview with a man, who was 19 years of age when he joined, suggests:

I got myself associated with the new organisation in 1967, which was formed right after the incident of Naxalbari, to assist the struggle and promote the ideas it upheld. ...() To be specific, the committee was dedicated to organise the peasants' struggle and propagate the politics of Naxalbari and to unite the communist revolutionaries of India. It was the moment that I met comrade Charu Majumdar for the first time at a meeting where his overwhelming personality thoroughly inspired me. It was then, I decided to dedicate myself to the cause of revolution. I started working with the local unit of the committee.

Conflicts between professors and students shaped the emergence of the movement, but with involvement, teacher-student relationships were reaffirmed on a more egalitarian basis through everyday practices. In the words of one former activist, these transformations were as subtle as they were truly 'revolutionary', 
given that they occurred in a context within which deferential treatment of all elders is the norm.

In the view of the public, the role that leaders played in getting the younger generation involved has been much criticised, and the alleged authoritarian character of the movement is legendary. Within this discourse, younger generation activists are depicted as innocent and ignorant victims of their superiors, while leaders are said to have acted ruthlessly and irresponsibly to raise their own profile. No doubt, the gap in age, skills, and experience formed the basis for the ubiquitous hierarchy within the party, and a number of the former members I interviewed blamed the leadership for misjudgements and the unnecessary death or arrest of many young cadres. At the same time, these very same leaders were depicted as inspiring role models and are today still often treated with formal respect by those younger cadres, who are still in touch.

Taking a more processual view, it appears that the behaviour the elders established within the movement was crucially not informed by the morality of the hierarchical sphere of kinship (i.e. father and son relationships, or the stress on hierarchies between brothers), but the more egalitarian ideal that characterises friendships between men. While younger activists fully expected hierarchies reflecting difference of age and experience to prevail, the commitment to the cultivation of personal integrity among the Naxalites did challenge such notions. And unlike the older Communist parties, where leaders were respected for sacrifices made in the course of earlier political campaigns, it was predominantly the way the older generation related to younger cadres at the time that made these bonds persuasive and enduring.

This remarkable opposition between the structural differences in age and the experience of the intimate relationship within the small groups operating in Calcutta and later on in prison dominates the accounts of former activists. Younger cadres blamed the senior leaders for tactical mistakes but emphasised that they had become close friends. They described in detail how the older comrades mixed freely with young activists and highlighted how the sharing of everyday tasks and facilities signified the truly revolutionary spirit among the leaders. The egalitarian discourse around sharing played a major role in their accounts. The following example presented by Suresh relates the importance of such practices:

I always respected the leaders and admired them because although they were older than we were, some of them were in their fifties, it was about the way they spoke to us and the way they sat with us, sharing cigarettes. They offered us cigarettes and we smoked together, that was a taboo of course, and still isjust today I met a former teacher when I went out to buy a packet of cigarettes and we both pretended that we did not notice the stand with cigarettes in front of us-though he clearly knew what I was doing there. That is still embarrassing, and so it was special that these older Communists smoked with us.

Where the older cadres and leaders were concerned, some of these practices had been part of their earlier training as members of the Communist Party of India (CPI), but even they conceded that the Naxalbari experience was different from 
their earlier politics. This, they alleged, was partly a result of the counterinsurgency measures, but also the sheer number of young people mobilised. Given the loose organisational structure of the CPI(ML) and the need for secrecy, mutual trust and clandestine operations, leaders depended as much on their junior comrades as on the older generation. The need to share ideas and expertise, but also food and shelter, facilitated close bonds between younger and older cadres, and the relationships formed through formal teaching sessions initially attended by students from their homes became even more intense through such everyday practices as common meals and time spent underground and imprisonment. No doubt there also existed intimate relationships between some of the comrades, though unlike the sexual freedom enjoyed by heterosexual couples, these were never discussed in the course of the life histories I collected.

But what activists were prepared to reveal was that some former comrades still utilised their activist network for specific purposes. I was first told about the "extended families of activists" when I was on my way to visit one of the most senior Naxalites still actively involved in politics. Then an octogenarian living alone in a remote suburb, this former CPI(ML) member was at the time, according to the friend who accompanied me, among the most influential in the party. He had lost touch with most of the younger activists once they came back from prison precisely because he had never publicly taken responsibility for sending young men on dangerous and sometimes fatal missions. However, now an old men and ailing, the party he still served, had offered him financial assistance to meet his daily expenses and rising medical costs.

My interlocutors saw this kind of support as an extension of earlier networks activists had developed when underground, where sympathisers and family members cooperated with each. For young activists, who unlike their senior comrades had no jobs and nuclear family to return to, family and party soon overlapped, and so did the morality of support: in the period after their release, those with proper jobs looked after their comrades, while younger cadres were called upon to do their seniors favours. This morality of mutual dependence has led to the repression of any public recognition on the ambiguity many young cadres felt towards the organisation and its leaders.

The lack of critical debate was brought to the fore by a very bitter former activist, who found himself at the mercy of his family when he was released from prison. When speaking to me, he actively sought 'to set the record straight' and to lend a voice to those, who like him, despised the leaders and their actions, which he described in terms of their 'hunger for prestige'. When I related that I had nevertheless observed that former leaders were treated with respect, he quoted a proverb which translates as 'when you eat mangoes don't drink water to avoid stomach pain.' In his view it demonstrated that party members were linked through a common morality like 'the members of a joint family', so they would never wash their dirty linen in public.

This and other examples highlight that it was not hierarchy or coercion that created the type of loyalty displayed by Naxalites in the course of the movement and often beyond. Rather, the morality of reciprocity commonly found among kin informed relationships that were in the view of the general public opposed to the 
domestic sphere. Such relationships with other Naxalites were chosen individually, and younger comrades spoke very emotionally about them. Often their bonds with older cadres were still strong, and they were prepared to take responsibility for the older generation in the aftermath of the movement. However, issues of support are also crucial for many of the younger generation, who will not be offered party funds as readily as the former leaders. In most instances, young men who had been underground or imprisoned until the 1980s relied on their families for help after their return home and many never managed to secure a permanent job. The anger of some younger comrades has not abated. While the older activists managed to reintegrate themselves into certain reciprocal relationships, many former students are still stuck in inferior positions and depressing domestic situations.

With reference to the masculinities embodied here, two related traits attributed to Naxalites more generally are highlighted: personal integrity and unpretentious behaviour, an ideal distinctly associated with the morality of these comrades. These ideals are difficult for householders to live up to, and activists who did start a family after prison were often depressed about the pressures and compromises that life as a family man entails. But those who remained single-either because their commitment to political work or because their families did not find suitable partners for marriage-face a different set of problems, especially as they are today getting older and their position in the local may remain unstable.

To avoid attachment is of course a theme that runs through the literature on renunciation in South Asia, and informs political autobiographies on the left and the right. Apart from Gandhians, early Communists did often remain unmarried and gave up family life to serve the cause. Interestingly, many former activists and others pointed out that today only the Naxalite cadres command the self control necessary to live according to the high moral standards of an idealised political life course. Ray states that an emphasis on trust 'not in its theoretical or strategic capabilities or perspectives, but its morality' (Ray 1988: 117) drew young men into the movement. This ties in with generalised attitudes to politics, which associate trust and personal integrity as a prerequisite to successful leadership, though not to politics per se (see Banerjee 1999; Ruud 2000). The fact that such a morality is crucially attributed to former Naxalite activists in public discourse today has not only allowed the younger cadre to live with their bitter experiences during and after the movement, but also enabled some, mostly older cadres, to gain influence in local politics. While these established political activists are well-known and command a certain kudos in public life, it is the younger generation that in my view really makes a difference, because as my fieldwork has also shown, these Naxalites managed to carve out a different kind of personal politics for themselves.

\section{Conclusion}

The stereotypical opposition of the renouncer and the householder does clearly play an important role in South Asian ideal constructions of masculinity (i.e. Madan 1987; Fuller 1984), but it does not account for the multilayered Naxalite experience. Though it shaped nationalist imagery, former activists referred to very different 
historical trajectories, primarily ideals of politicised masculinity present in militant anti-colonial struggles of the Anushilan Samiti and the Jugantar groups and the Communist movement after independence (Kohli 1987; Khilnani 1997).

Naxal students of the 1970s modelled themselves on these secret revolutionary organisations, but instead of their open association with Hindu cultural forms, they presented such militant activism in the vocabulary of the Red Guards. This also indicates that they did not aspire to be activists deeply involved in domestic relationships and hierarchies, but that they relied instead on the historical links between militant terrorism and the morality of friendships between men. Here, concepts of masculinity are based on reciprocity, sharing and exchange among male friends, sexual freedom, and a notion of brotherhood—which are clearly constructed in contrast to filial duties and kin bonds.

The life histories and interviews presented here provide insights into the various aspects that activists deemed relevant, where challenges to hegemonic models of masculinity are concerned. While they sourced their legitimacy from the morality associated with all those who joined the movement, they also draw attention to silences - about sexual exploitation, about hierarchies and the failure of leaders to own up to their actions. Obvious and legitimate practices appeared side by side with other, equally relevant experiences, which official discourses and politically correct representations have relegated to the multiple kinds of 'privatised memories' of a movement that ultimately failed to deliver a better world.

The personal testimonies that I have analysed here can help us to reconsider the value of experience in debates within the social sciences, such as the scholarship on the gendered aspects of militant activism. Arnold and Blackburn observe that life histories can assume the form 'of an unnarrativized social memory, transmitted through anecdotes or other expressions of popular consciousness' (Arnold and Blackburn 2004: 11). The autobiographical sketches of former political activists that inform the ethnography here provide such an alternative view on gender roles and idealised constructions of a past dedicated to a progressive ideology, as they highlight the emancipatory effects of public involvement for men from middle-class backgrounds. In this sense, life histories can foreground political subjectivities and sensibilities which are excluded from canonised accounts. But to solely see the life histories on which this article is based as examples of South Asian political hagiographies would limit their value as testimony or historical work by means of personal accounts (Arnold and Blackburn 2004).

Naxalite testimony contributes to the growing body of work on political memory, historical crisis and state policies in South Asia (Butalia 1988; Chatterjee 1992; Tarlo 1995; Panjabi 1997; Menon and Bhasin 1998; Kaul 2001). However, given that the subjects here are male middle-class activists, their accounts sit rather uneasily with those scholarly reworkings that represent marginalised groups, including women and peasants within the context of movements. The ethnography of personal stories suggests that men who were active in the movement challenged hegemonic discourses as much as their female comrades did. By contesting ideals of filial duty and the acceptable masculine life course these activists experienced the rupture of kin relations, but also see the formation of very different relationships between men as empowering. For many, this process provided the space for a 
rethinking of everyday politics, and in particular their choice of networks, which often pushed the boundaries between moralities allegedly applied within the family, and 'outside'. Unlike other persecuted groups, my interlocutors did not focus on their own roles as victims, but in the course of the interviews reflected on the way their involvement shaped their personal lives and the lives of the people around them.

Not all Naxalites carved out positive new roles for themselves in terms of practices or in terms of representations. And only a few allowed a radical political masculinity to enter and inform the private sphere. But reading the Maoist experience as a challenge to hegemonic ideologies regarding a range of relationships even within the wider kin group, allows us to reinsert the revolutionary content of practices into the history of the everyday. Last but not least, a 'life history' approach shows that new visions of the social emerged through the bonds the movement fostered, which is equally true for men as it is for women. These affinities were in many cases maintained beyond the lifespan of the movement and did not simply replicate historical patterns. They still bind the former comrades together in complex ways, resting as they do on shared experience and values as well as the necessity of social support. Drawing on culturally specific notions of relatedness, they constitute the morality of kinship in other spheres, and are thus a constant reminder of a radical past that keeps challenging the present.

Acknowledgments Research in Calcutta was carried out between 1999 and 2005 and was supported by the ESRC and the Suntory and Toyota International Centre for Economics and Related Disciplines. I am greatly indebted to those who shared their experiences and views with me, in particular Gautam Banerjee. For obvious reasons the identities of former activists are disguised. Earlier versions of this article were presented at the EASA conference in Bristol and the Centre for South Asian Studies, University of Edinburgh and I am grateful for critical comments by Radhika Chopra, Sharika Thiranagama and John Hutnyk, Alpa Shaw and Judith Pettigrew. Parts of this article have been published earlier (see Donner 2004a, b).

\section{References}

Arnold, D., and Stuart Blackburn (ed.) 2004. Introduction. In Telling lives in India: Biography, autobiography, and life history, pp. 1-29. Bloomington: Indiana University Press.

Bandyophadyay, K. 2008. Naxalbari Politics: A feminist narrative. Economic and Political Weekly 43:52-59.

Banerjee, S. 1987. Thema book of Naxalite poetry. Calcutta: Thema.

Banerjee, M. 1999. Mamata's Khomota. Seminar 480: 30-35.

Basu, P. 2000. Towards Naxalbari (1953-1967): An account of inner-party ideological struggle. Calcutta: Progressive Publishers.

Butalia, U. 1988. The other side of silence: Voices from the partition of India. Delhi: Penguin.

Chatterjee, N. 1992. Midnight's Unwanted Children: East Bengali Refugees and the Politics of Rehabilitation. Ph.D Thesis Brown University.

Chopra, R., C. Osella, and Filippo Osella. 2004. Masculinities in South Asia. Delhi: Kali for Women.

Dasgupta, B. 1974. The Naxalite movement. Bombay: Allied Publishers.

Dasgupta, S. 1996. Recalling Naxalite terror. Indian Express, June 29.

Devi, M. 2001. Mother of 1084. Calcutta: Seagull Books.

Donner, H. 2004a. The significance of Naxalbari: Accounts of personal involvement and politics in West Bengal, Occasional Papers Series, Centre for South Asian Studies, Cambridge University, vol 3, no 2, pp. 1-21. 
Donner, H. 2004b. 'The legacy of the Maoists in West Bengal' talk at the LSE Asia centre. www. lse.ac.uk/collections/asiaResearchCentre/pdf/LegacyOfMaoistsInWestBengal ByHDonner.doc.

Franda, M.F. 1971. Radical politics in West Bengal. Cambridge: M.I.T. Press.

Fuller, C.J. 1984. Servants of the Goddess: The priests of a South Indian temple. Cambridge: Cambridge University Press.

Ghosh, S. 1974. The Naxalite movement: A Maoist experiment. Calcutta: Firma K. L. Mukhopadhyay.

Iguarta, J., and Dario Paez. 1997. Art and remembering traumatic collective events: The case of the Spanish Civil War. In Collective memory of political events: Social psychological perspectives, ed. J.W. Pennebaker, D. Paez, and Bernard Rimé, 79-101. Mahway, New Jersey: Lawrence Erlbaum Associates.

Kaul, S. (ed.). 2001. The partitions of memory: The afterlife of the division of India. Delhi: Permanent Black.

Khilnani, S. 1997. The idea of India. London: Hamish Hamilton.

Kohli, A. 1987. The state and poverty in India: The politics of reform. Cambridge: Cambridge University Press.

Lamb, S. 2000. White saris and sweet mangoes: Aging, gender and body in North India. Berkeley: University of California Press.

Madan, T. N. 1987. Non-renunciation: themes and interpretations of Hindu Culture. Delhi: Oxford University Press.

Menon, R., and Kamla Bhasin. 1998. Borders and boundaries: Women in India's partition. New Brunswick: Rutgers University Press.

Mitra, A. 1985. Calcutta diary. Calcutta: Circa.

Mitra, T. 2001. Winds of change. Telegraph April 22.

Mitra, J. 2004. Killing days: Prison memories. Delhi: Kali for Women.

Mukhopadhyay, A.K. 2006. The Naxalites through the eyes of the police: Selected notifications from the Calcutta police gazette, 1967-1975. Calcutta: Dey's Publishing.

Nossiter, T.J. 1988. Marxist state governments in India: Politics, economics and society. London: Pinter Publishers.

Paitnak, P. 2007. In the aftermath of Nandigram. Economic and Political Weekly 42(21): 1895-1898.

Panjabi, K. 1997. Probing "morality" and state violence: Feminist values and communicative interaction in prison testimonies in India and Argentina. In Feminist genealogies, colonial legacies and democratic futures, ed. M.J. Alexander, and Chandra Talpade Mohanty, 151-169. London: Routledge.

Ray, R. 1988. The Naxalites and their ideology. Delhi: Oxford University Press.

Roy, S. 2007. The everyday life of revolution: Gender, violence and memory. South Asia Research 27: 187-204.

Ruud, A.E. 2000. Talking dirty about politics: A view from a Bengali village. In The everyday state and society in modern India, ed. C. Fuller, and Véronique Bénéi, 115-136. New Delhi: Social Science Press.

Sinha-Roy, M. 2007. Gender and politics in Bengal: Women's participation in the Naxalbari-Movement in West Bengal (1967-1975). Ph.D Thesis University of Oxford.

Tarlo, E. 1995. From victim to agent: Memories of the emergency from a resettlement colony in Delhi. Economic and Political Weekly 30: 2921-2928. 